THURSDAY, JULY 23,1874

\section{THE PUBLIC SCHOOLS COMMISSION}

THE claims of science to form an integral part of a liberal education are, without doubt, making progress. Readers of the early numbers of NATURE will remember how it was, with justice, complained that scarcely a single Scholarship or Fellowship was to be obtained at the old Universities for science alone. In more recent numbers the statement has to be modifiedthere is not yet a sufficient proportion. Now it is acknowledged on all hands, that the teaching of a subject at school and its recognition at the Universities are inseparably connected-and especially with regard to science. The Colleges say, We cannot give more scholarships, because a sufficient number of men of good attainments do not present themselves; and the Schools reply, We cannot spend our time on subjects for which there are so few rewards. Both profess willingness, but each calls on the other to take the initiative. One might, perhaps, be inclined to wonder that this question of pecuniary rewards should be of so much consequence as consciously to override the acknowledged main object in view-that of giving the best possible education. But it must be remembered that scholarships at the Universities are the honours of a school-the only means it has of showing to the world that it is doing its work well.

The progress due to the stimulus of scholarships is from these reasons slow, though perceptible; and the friends of science have been looking therefore to the Royal Commissions on Scientific Instruction, and on the Public Schools, to supply a stimulus from another quarter.

The proposed "Regulations" of the latter Commission which have just been issued will be welcomed by those who heartily wish for the progress of Science Teaching. Ignoring, of course, the question of University scholarships, they indirectly settle it by placing science on exactly the same level as mathematics, and enforcing the necessary outlay for its efficient teaching. And there can be little doubt that this is the right end at which to begin the reform, for it is a narrow view to consider the Universities as making the demand by offering rewards, and the schools as affording the supply. It is the public that demand scientifically educated men, and the schools first, and then the Universities, are called upon to supply them.

These Regulations apply, of course, to a very limited number of schools, some of which have already done much that is now required of them ; but they are the most important schools in the kingdom, and will inevitably influence all others by the standard thus set. If these Regulations be confirmed the nail will be driven home, and science will be established as a necessary part of every public school curriculum.

The following are the Regulations to which we especially draw attention, and which are common to all the schools in the view of the Commission :-

" 2 . In every examination determining the position of a boy (not being one of the senior boys) in the school, or in any report of a general examination, the proportion of the marks to be assigned to mathematics shall be not less than one-eighth, nor more than one-fourth, as the governing body may think fit.

" 3 . In every examination determining the position of a boy (not being one of the senior boys) in the school, or in any report of a general examination, the proportion of the marks to be assigned to natural science shall be not less than one-eighth, nor more than one-fourth, as the governing body may think fit.

"4. In any examination for the senior boys, the proportion of the marks to be assigned to the several subjects of study shall be determined by the head master, with the approval of the governing body.

" 5 . The governing body shall from time to time determine the point in the school list above which the boys shall be reckoned as senior boys for the purposes of these regulations.

" 6 . The head master shall give facilities so far as practicable to any senior boy, at the request of his parent or guardian, to pursue any particular subject or subjects of study as may be deemed most expedient for him, and to discontinue any other subject or subjects of study for that purpose.

"7. The governing body shall, as soon as possible, provide and maintain out of the income of the property of the school, or out of any other means at their disposal for the educational purposes of the school, laboratories, and collections of apparatus, and of specimens."

It will be observed that the wording of Nos. 2 and 3 is identically the same, except the substitution of the words Natural Science for Mathematics--thus placing these two subjects upon exactly the same level. With regard to the limits one-fourth and one-eighth,taking it as approximately correct that the proportion of marks in an examination will be that of the time devoted to the subject, these two together will require at least one-fourth of the whole time, a larger proportion than is now given to mathematics in most schools, especially with those who are not "senior boys ; "and thus an encroachment on the classical time is involved, and this lower limit is not likely, therefore, to be much exceeded, in these great schools at all events. But even this will insure greater breadth than under the old system, and will secure that every boy shall know something of the elements of science before he goes on to the elegancies of classics.

The individual character, however, of particular schools is not interfered with, for this depends essentially on the work of the senior boys ; and for them by Regulation 4 the head master may arrange the marks to suit the old traditions of the school. Yet, when we consider the effect of Nos. 6 and 7, we may doubt whether the individuality will continue so well marked. For with laboratories to work in, and specimens to handle, and facilities to pursue their favourite subject, it is impossible but that some fair proportion of the scholars should be attracted by the charms of physical investigation or of natural history, and mix the honours of the school.

Of all the proposed Regulations, however, the most pregnant with consequences is the last.

There is no need surely in these days to insist on the absolute necessity for "laboratories and collections of apparatus and of specimens," if science is to be taught at all; and we may look, therefore, on this as simply the definition of the term "Natural Science ;" it is not book learning, but science learnt from Nature herself by practical work. If a governing body be called on to provide such laboratories, we may rely on it that for the credit of their school they will do it well, and a good laboratory 
leaves only a good teacher to be desired, and itself helps to form and train him. The confirming of this Regulation will be a great step towards that much-to-be-desired state of things when a laboratory will be considered as necessary a part of a school as a class-room, bottles and bones as essential as books and boards. But we must not ignore what has already been done in schools like Eton and Rugby; with their laboratories and museums, such a Regulation is superfluous; but with the good work which has been accomplished before us, we have a happy omen of the result of the universal application of the principle they have voluntarily aclopted. It is from these schools and others not included in the "nine," that have not fitted up their laboratories, that the Natural Science scholars are obtained, and perhaps the proportion of such scholarships to all others is as great as that of schools with laboratories to those without-probably greater. As the number of science-teaching schools increases the number of scholarships must increase too, but not at the same rate ; the proper and final proportion may be left to settle itself.
On the whole we may regard these proposed Regulations with the greatest satisfaction, and it is probable that they will be looked back upon as the charter of the country's progress in scientific education. Individual efforts have been made on a grand scale, and natural science is making its way more or less efficiently into all good schools, while some are devoting themselves chiefly to its cultivation, as Taunton, Giggleswick, Burnley ; but universal recognition, its acquirement of prestige, and consequent respect and earnest study, with the national advantages to be derived from it, can only be secured by such Regulations as these, followed or not as may be neces. sary, by similar ones for all the larger endowed schools.

\section{THE SUB-WEALDEN EXPLORATION}

$\mathrm{T}$ the word romance were to be imported into scientific 1 literature there could surely be no more fitting application of it than to this recent crusade into the bowels of the earth among the woods and lanes of Sussex. Down in that southern part of the country, some hundreds of

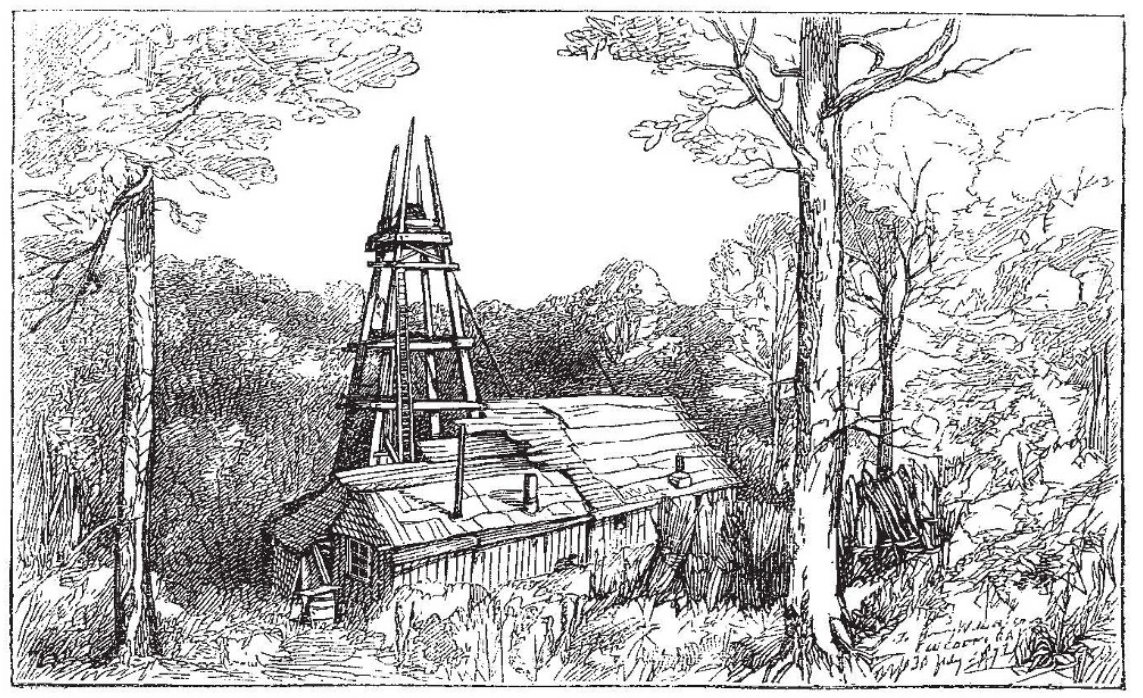

The Sub-Wealden Exploration in Sussex-Boring at Netherfield. (Kindly lent by the Proprietors of the Graphic.)

miles áway frem the great centres of our mineral industry, with no prospect of any pecuniary reward or of any immcdiate economic advantage, men are found willing to subscribe money to the extent of thousands of pounds for the purpose of settling definitely some important questions in the geology of the south-east of England, viz. at what depth from the surface the secondary strata are underlain by a ridge or platform of old Palæozoic rocks, what are the nature and age of these bottom rocks of the district, and what is the arrangement of the strata lying between them and the surface. It has long been a problem of much interest to geologists to discover whether or in what manner the great series of Jurassic rocks, which stretches across our island from the coasts of Dorsetshire to those of Yorkshire, passes south-eastward underneath the chalk. That series has been found to grow thinner towards the south-east. On the French side of the Channel it reappears in the Boulonnais, coming out from under the Cretaeeous strata and resting against a ridge of
Palæozoic rocks which rise to the surface between Boulogne and Calais. Nearly twenty years ago $\mathrm{Mr}_{\mathrm{r}}$. Godwin Austen drew attention to the probable extension of this ridge underneath the later formations of the south-east of England and its connection with the Carboniferous tracts in our south-western counties. It was a point of great interest in any attempt to reconstruct a map of the physical geography of western Europe during Palaozoic times. Hence, at intervals since the publication of $\mathrm{Mr}$. Austen's great memoir, renewed attention has been given to the subject, until at last the idea took shape that a bold attempt should be made to settle some portion at least of the problem by putting down a bore and keeping it going, if possible, until all the Secondary rocks should be pierced and definite information should be obtained as to what lies below them. Advantage was taken of the meeting of the British Association at Brighton in 1872 to organise the scheme. For so purely scientific a project it was of course natural to look for help mainly to such well-wishers 